\title{
The Role of Logo Redesign in Creating Brand Value
}

\author{
Seyed Mahmoud Shabgoo Monsef \\ Department of industrial management, Islamic Azad University \\ Rasht Branch, Rasht, Iran \\ Tel:+98-911-333-1968 E-mail: M_monsef53@yahoo.com \\ Seyyed Javad Mousavian \\ Department of Business management, Islamic Azad University \\ Rasht Branch, Rasht, Iran \\ Tel: +98-911-335-4617 E-mail:saba_moosaviyan@yahoo.com \\ Shahram Gilaninia (Corresponding author) \\ Department of industrial management, Islamic Azad University \\ Rasht Branch, Rasht, Iran \\ Tel: +98-911-335-6977 E-mail: gilani_sh45@yahoo.com
}

Received: March 14, 2011 Accepted: June 2, 2011 doi: 10.5430/jms.v2n2p46

\section{Announcement of Retraction}

The editorial board has recently confirmed that this article violated the journal's prepublication policy. Therefore, we hereby notify our readers that the paper has been retracted on December 8, 2011.

Should you have any further question, please contact us at: jms@sciedu.ca

\section{Article's information}

Article Title: The Role of Logo Redesign in Creating Brand Value

Journal Title: Journal of Management and Strategy, ISSN 1923-3965 E-ISSN 1923-3973

Volume and Number: Vol. 2, No. 2, 2011

Pages: p46 